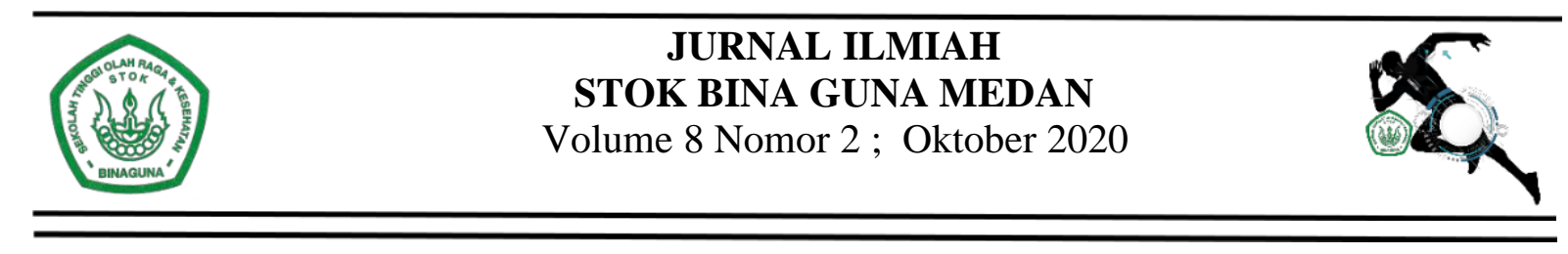

\title{
PELAKSANAAN MANAJEMEN PEMUSATAN PENDIDIKAN DAN LATIHAN OLAHRAGA BAGI PUSAT PEMBINAAN LATIHAN MAHASISWA (PPLM) CABANG OLAHRAGA KARATE KOTA BANDA ACEH
}

\author{
Yahya $^{1}$ Irfandi $^{2}$ \\ Dosen Universitas Jabal Ghafur Sigli \\ Dosen STKIP Bina bangsa Getsempena Banda Aceh \\ E-mail: yahya.ak@gmail.com
}

\begin{abstract}
ABSTRAK
Kajian penelitian ini bertujuan untuk: (1) Mengetahui struktur organisasi Pusat Pembinaan Latihan Mahasiswa (PPLM) tarung derajat Kota Banda Aceh (2) Mengetahui proses tahapan yang dilakukan dalam perekrutan atlet di Pusat Pembinaan Latihan Mahasiswa (PPLM) tarung derajat Kota Banda Aceh (3) Mengetahui manajemen sarana dan prasarana dalam mendukung prestasi atlet Pusat Pembinaan Latihan Mahasiswa (PPLM) tarung derajat Kota Banda Aceh. (4) Mengetahui pelaksanaan manajemen keuangan di Pusat Pembinaan Latihan Mahasiswa (PPLM) tarung derajat Kota Banda Aceh. (5) Mengetahui pelaksanaan manajemen latihan Pusat Pembinaan Latihan Mahasiswa (PPLM) tarung derajat Kota Banda Aceh. Penelitian dilaksanakan di Balai Pusat Pembinaan Latihan Mahasiswa (PPLM) tarung derajat Kota Banda Aceh. Penelitian ini menggunakan metode diskriptif kualitatif. Unit analisisnya adalah Balai Pusat Pembinaan Latihan Mahasiswa (PPLM) tarung derajat Kota Banda Aceh.

(1) Struktur Organisasi Pusat Pembinaan Latihan Mahasiswa (PPLM) tarung derajat Kota Banda Aceh sudah baik yang mana sudah memiliki unsur-unsur organisasi yang terus berupaya memfasilitasi atlet untuk berprestasi. (2) Proses perekrutan atlet sudah dilaksanakan dengan baik karena sangat selektif dan sudah sesuai dengan kriteria/bencmark yang ditentukan oleh standar Kemenpora Republik Indonesia (3) Pelaksanaan manajemen sarana dan prasarana kurang baik, hal ini dikarenakan media pendukung fasilitas atlet PPLM belum lengkap sepenuhnya dan hanya memanfaatkan apa yang ada saja. (4) Pelaksanaan manajemen keuangan telah dilaksanakan dengan baik karena sudah sesuai dengan porsinya masing-masing. (5) Pelaksanaan manajemen latihan di Pusat Pembinaan Latihan Mahasiswa (PPLM) tarung derajat KotaBanda Aceh sudah berjalan dengan baik. Mengingat alokasi dana dari APBN dan ABPD yang terbatas pada setiap tahunnya, sehingga pengelolaan hanya memaksimalkan sesuai dengan alokasi danayangada.
\end{abstract}

Kata Kunci: Pelaksanaan Manajemen PPLM, Struktur Organisasi, Perekrutan Atlet, Manajemen Sarana Prasarana Manajemen Keuangan dan Latihan 


\section{PENDAHULUAN}

Puncak pencapaian prestasi lahraga merupakan salah satu wujud dari upaya peningkatan kualitas manusia yang bertujuan untuk pembentukan watak dan kepribadian, disiplin dan sportifitas yang tinggi, serta peningkatan prestasi yang dapat membangkitkan rasa kebanggaan nasional. Dilain sisi prestasi dalam bidang olahraga merupakan salah satu tolok ukur suatu kemajuan bangsa yang mempunyai peran sangat penting bagi upaya pembentukan dan peningkatan kualitas sumber daya manusia untuk pembangunan.

Proses pengembangan prestasi olahraga tersebut tentunya membutuhkan atlet-atlet yang memiliki potensi yang tinggi. Untuk mendapatkan atlet berpotensi maka perlu adanya pembinaan dan pengembangan prestasi pada usia produktif yakni tingkat usiasekolahDault, A. (2014:8).

Berdasarkan arah tersebut di atas maka pemerintah mendirikan model pembinaan di kalangan pelajar yang disebut dengan Diklat pelajar di beberapa propinsi di Indonesia dengan objek sasaran pelajar terutama siswa dan mahasiswa atau yang disebut dengan Pusat Pembinaan Latihan Mahasiswa (PPLM) tarung derajat Kota Banda Aceh, yangsekarangdiubah menjadi balai Pusat Pembinaan Latihan Mahasiswa (PPLM) tarung derajatadalah sumber daya manusia yang paling tepatuntukmenjadi sasaran mencari cikalbakalmunculnyaatlet berprestasi di masa yangakandatang.

Dalam perjalanan usianya yang sudah relatif lama, PPLM yang sekarang tetap tidak berganti nama menjadi PPLM telah berhasil menyumbangkan sejumlah atlet junior Nasional dibeberapa cabang olahraga untuk mewakili Indonesia di arena regional maupun internasional. Salah satu olahraga yang menyumbangkan atlet junior adalah Tarung Derajat(Box).

Kejuaraan yang diikuti oleh atlet PPLM antara lain yaitu Popnas (Pekan Olahraga Pelajar Nasional) yang diadakan dua tahun sekali pada tahun ganjil, Popwil (Pekan Olahraga Wilayah) yang diadakan dua tahun sekali pada tahun genap, Kejurnas (Kejuaraan Nasional) yang diadakan satu tahun sekali. Disanalah tempat bertanding kompetisi tingkat nasional para atlet PPLM untuk menunjukkan keunggulan masing-masing wilayah dan juga membuktikan sejauh mana latihan yang dilakukan setiap harinya membuahkan hasil ataukah tidak. Kenyataan di lapangan dalam Popnas, Popwil, dan Kejurnas cabang sepak takraw dari tahun 2007 sampai dengan sekarang (2017) Pusat Pembinaan Latihan Mahasiswa (PPLM) tarung derajat Kota Banda Aceh adalah PPLM cabang tarung derajat yang selalu keluar menjadi juaranya.

Disisi lain sarana dan prasarana atlet tergolong kurang memadaiAmbar, T., Sulistiyani R (2010:12). Asrama dan tempat latihan yang ala kadarnya dan cenderung tidak memenuhi standart. Dengan kesenjangan tersebut tentunya Pusat Pembinaan Latihan Mahasiswa (PPLM) tarung derajat Kota Banda Aceh perlu diamati. Pasti ada faktor pelaksanaan manajemen tertentu yang menyebabkan Pusat Pembinaan Latihan Mahasiswa (PPLM) tarung derajat Kota Banda Aceh selalu keluar menjadi juara umum sejak tahun 2007 sampai sekarang.

Dengan kata lain PPLM yang minim perhatian tentang sarana dan prasarana atlet tetapi tetap bisa berprestasi. Dengan berdasarkan pada latarbelakang yang dikemukanan sebelumnya, maka rumusan masalah yang akan dikemukakan adalah: 
Bagaimana struktur organisasi Pusat Pembinaan Latihan Mahasiswa (PPLM) tarung derajat Kota Banda Aceh? Bagaimanakah proses tahapan yang dilakukan dalam perekrutan atlet di Pusat Pembinaan Latihan Mahasiswa (PPLM) tarung derajat Kota Banda Aceh? Apakah sarana dan prasarana yang dibutuhkan telah sesuai dengan kebutuhan atlet pelajar? Bagaimanakah pelaksanaan manajemen pendanaan di Pusat Pembinaan Latihan Mahasiswa (PPLM) tarung derajat Kota Banda Aceh? Bagaimana pelaksanaan manajemen latihan Pusat Pembinaan Latihan Mahasiswa (PPLM) tarung derajat Kota Banda Aceh.

\section{METODE PENELITIAN}

Jenis penelitian yang digunakan adalah penelitian kualitatif dan bersifat deskriptifLutan, R., Suherman, A. (2010:90). Alasan yang mendasarinya adalah karena dalam penelitian ini mengambil masalah keadaan penerapan manajemen Pusat Pembinaan Latihan Mahasiswa (PPLM) tarung derajat Kota Banda Aceh, yang disajikan secara deskriptif, bukan merupakan pernyataan jumlah dan tidak dalam bentuk angkaangka

Penelitian ini akan dilakukan di Balai Pusat Pembinaan Latihan Mahasiswa (PPLM) tarung derajat Kota Banda Aceh. Teknik pengambilan sampel yang digunakan adalah purposive sampling dan snowball sampling. Sumber data dalam penelitian ini meliputi para pengelola, pelatih dan atlet Pusat Pembinaan Latihan Mahasiswa (PPLM) tarung derajat Kota Banda Aceh. Teknik Pengumpulan data dilakukan dengan cara mengkaji data dan arsip (content analysis), wawancara mendalam

(in-

depth interviewing), observasi (observation). Selanjutnya dilakukan reduksi data untuk pemfokusan, penyederhanaan dan kemudian dilakukan deskripsi dalam bentuk narasi yang memungkinkan simpulan penelitian dapat dilakukan.Sedangkan untuk, menetapkan keabsahan data digunakan teknik pemeriksaan dengan empat kriteriayaitu derajat kepercayaan(credibility),keteralihan (transferability),

$\begin{array}{ll} & \text { kebergantungan } \\ \text { (dependability), } & \text { dan } \\ & \text { kepastian }\end{array}$

(confirmability).Data yang dianalisis secara kualitatif berasal dari data yang diperoleh dari berbagai sumber yaitu wawancara. Tahap analisis data yangdilakukan dalam penelitian ini sebagaimana yang dilakukan yaitu: (1) Pengumpulan Data, (2)Penyajian Data, (3) Reduksi Data, (4) Penarikan Kesimpulan/Verifikasi.

\section{HASIL DAN PEMBAHASAN}

Berdasarkan pada seluruh rangkaian penelitian dan pengambilan data dari berbagai sumber yang ditemui oleh peneliti maka didapatkan beberapa data yang kemudian menjadi pendukung ketercapaian temuan-temuan penting dalam penelitian ini. Data-data ini diharapkan dapat menjawab rumusan masalah atau juga dapat memberikan banyak informasi yang dapat berguna bagi siapa saja yang membutuhkan. Berikut hasil data yang didapat dari berbagai sumberinformasi:

\section{Struktur Organisasi PPLM Tarung Derajat Kota BandaAceh}

Cabang olahraga sepak takraw pelajar di Indonesia berada dalam naungan organisasi. Pusat Pembinaan Latihan Mahasiswa (PPLM) tarung derajat Kota Banda Aceh. Koordinasi dalam organisasi 
PPLM ini sangat diperlukan untuk mendapatkan dukungan yang optimal dari berbagai pihak terkait sebagai pengguna atlet berprestasi.

Untuk menyelenggarakan suatu pengelolaan pembinaan idealnya mempunyai struktur organisasi seperti struktur organisasi pada pengelolaan pembinaan pusat (Deputi Binpres \&Iptek Olahraga Kemenegpora, R.I: 2016) yaitu terdapat (1) Pembina, (2)penanggung jawab, (3) Ketua Pelaksana, (4)

Ketatausahaan, (5) Pelaksana Harian, (6) Pelajar. Secara keorganisasian PPLM Tarung Dearajatsudah baik dengan semua unsur-unsur organisasinya yang memiliki tugas masing-masing menurutjabatannya.

\section{Proses Tahapan yang Dilakukan dalam Perekrutan Atlet PPLM Tarung Derajat Kota Banda Aceh}

Gambaran tentang pelaksanaan proses tahapan yang dilakukan dalam perekrutan atlet pelajar di Pusat Pembinaan Latihan Mahasiswa (PPLM) tarung derajat Kota Banda Aceh, menunjukkan bahwa proses tahapan yang dilakukan dalam perekrutan atlet sudah berjalan dengan baik, terlihat dari promosi yang berjalan dengan baik, hal ini terlihat dari peserta yang mendaftar terdiri dari banyakkabupaten/kota.

Karena sosialisasi yang baik dari pengelola Pusat Pembinaan Latihan Mahasiswa (PPLM) tarung derajat Kota Banda Aceh dalam hal ini Dinas Pemuda dan Olahraga ke sekolah-sekolah yang ada di Kabupaten/Kota Banda Aceh. Proses yang dilaksanakan sudah sesuai prosedur yang telah ditentukan sebelumnya dengan mengikuti aturan - aturan yang ada, atlet mengikuti tahap demi tahap proses pelaksanaan seleksi yaitu 3 hari dan merujuk buku panduan yang dikeluarkan oleh Kemenpora dan bench marking Kemenpora R.I.

Tes yang dilakukan oleh pengelola Pusat Pembinaan Latihan Mahasiswa (PPLM) tarung derajat Kota Banda Aceh sudah sesuai dengan benchmark yang dikeluarkan oleh Kemenpora walaupun peralatan tergolong masihkurang.

Kendala-kendalanya adalah atlet yang dikirimkan oleh kabupaten/kota50 \% adalah bukan atlet, dan 50\% nya lagi adalah atlet pemula dari club-club cabang olahraga. Dilihat dari simetris tubuh (antropometri), masih banyak kabupaten/kota mengirimkan atletnya dengan tinggi badan masih dibawah rata- rata. Dalam melaksanakan tes, perlu memperhatikan urutan pelaksanaan pengukuranFatah, $\mathrm{N}$. (2013:20)..

Jenis-jenis pengukuran yang dalam pelaksanaannya mengharuskan atlet mengeluarkanbanyak tenaga, hendaknya dilaksanakan di urutan terakhir, seperti pengukuran kapasitas aerobik, kapasitas aerobik maksimal dan kesegaran jasmani berdasarkan Panduan Penetapan Parameter Tes Pada Pusat Pendidikan dan Pelatihan Pelajar dan Sekolah Khusus Olahragawan. (Deputi Binpres \& Iptek Olahraga Kemenegpora,2016).

Dalam hal ini Pusat Pembinaan Latihan Mahasiswa (PPLM) tarung derajat Kota Banda Aceh pada pelaksanaan rekrutmen atlet pelajarnya sudah baik karena sudah merujuk pada buku panduan penetapan parameter tes yang dikeluarkan oleh Kemenpora Deputi Peningkatan Prestasi dan IptekOlahraga.

Pelaksanaan Manajemen Sarana dan Prasarana PPLM Tarung Derajat Kota Banda Aceh 
Rencana pengadaan sudah disusun dalam program kerja melalui Pusat Pembinaan Latihan Mahasiswa (PPLM) tarung derajat Kota Banda Aceh. Penentuan barang atau sarana yang akan dibeli dimusyawarahkan dengan seluruh Pusat Pembinaan LatihanMahasiswa (PPLM) tarung derajat KotaBandaAceh. Seperti

$$
\text { iventarisasi/alat latihan, }
$$

kebutuhan perlengkapan asramaatletdan fasilitasnya, perlengkapanstafkeuangan, tata usaha, kebersihandankeamanan lingkungan asrama dan lain- lain.

Pemanfaatan sarana dan prasaranalatihan telahoptimalsepertialat-alatlatihanyang di Pusat

PembinaanLatihanMahasiswa(PPLM) tarung derajat KotaBandaAceh. Begitu

$$
\begin{gathered}
\text { juga } \\
\text { penyimpanan peralatan latihan }
\end{gathered}
$$

yangada disesuaikan dengan tempatnya (setelahlatihanalat-alat dikembalikan). Pencatatandanpelaporan sudah ada

$$
\begin{gathered}
\text { seperti } \\
\text { inventaris } \\
\text { dipakai,daftarbarang,penerimaan dan } \\
\text { penggunaan }
\end{gathered}
$$

Laporandilakukan sejalandenganlaporan semesteran atau setara dengan enam (6) bulan sekali.

Adapun gambaran umum tentang pelaksanaan manajemen sarana dan prasarana Pusat Pembinaan Latihan Mahasiswa (PPLM) tarung derajat Kota Banda Aceh diatas menunjukkan bahwa nilai dari keterlaksanaan semua jenis kegiatan alhamdulillah sudah berjalan dengan baik meliputi perencanaan, pengorganisasian atau penyediaan, pendayagunaan atau pemanfaatan, penyimpanan atau pemeliharaan dan pencatatan data atau pelaporan. Subagio (2010: 12) mengemukakan bahwa pengelolaan sarana dan prasarana merupakan suatu proses kegiatan perencanaan, pengorganisasian, pengadaan, pemerliharaan, penghapusan, dan pengendalian logistik atau sarana dan prasarana olahraga. 


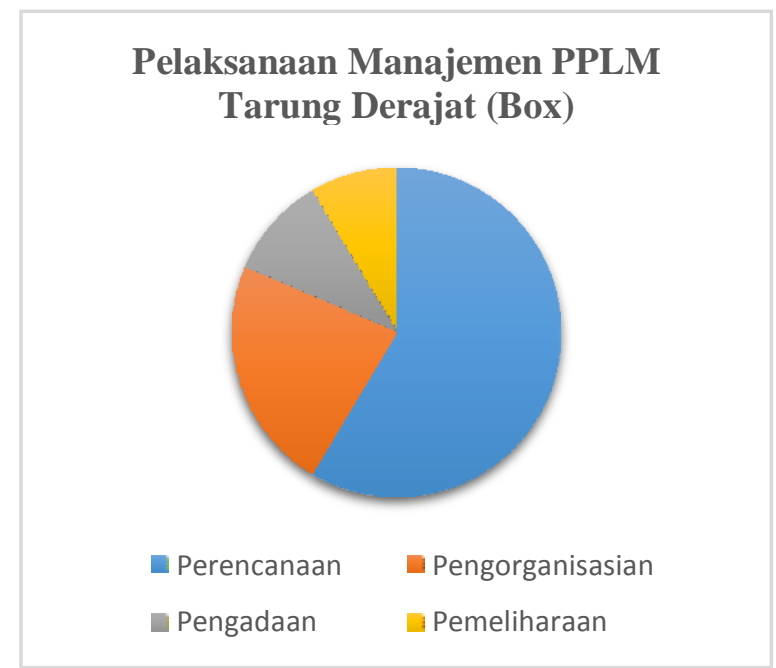

Sumber: hasil olah data, 2019

Pemeliharaan, perawatan sarana dan prasarana olahraga sudah cukup. Ini terlihat dari kebersihan dan keteraturan keadaan asrama Pusat Pembinaan Latihan Mahasiswa (PPLM) tarung derajat Kota Banda Aceh. Bangunan asrama memakai sistem bertingkat 2 (dua) sehingga halaman atau pekarangan asrama dapat dimanfaatkan untuk atlet latihan dan bermain.

Akan tetapi prasarana Pusat Pembinaan Latihan Mahasiswa (PPLM) tarung derajat Kota Banda Aceh terhadap latihan belum sepenuhnya baik, artinya Prasarana latihan yang mendukung hanya $60 \%$ saja dari keseluruhan cabang olahraga yang ada. Peralatan menunjang yang lain belum memadai seperti weight training yang masih minim atau peralatan lain penunjang latihan terutama pemanfaatan alat bantú latihan yang kurangstandar. Padahal untuk pengelolaan prasarana dan sarana di Pusat Pembinaan Latihan Mahasiswa (PPLM) tarung derajat Kota Banda Aceh dapat diartikan sebagai berikut:

a. Prasarana dan sarana yang dipergunakan dalam penyelenggaraan Pusat Pembinaan Latihan Mahasiswa
(PPLM) tarungderajat Kota Banda Aceh wajib memenuhi jenis, jumlah dan standarNasional.

b. Standarisasi prasarana dan sarana olahraga yang dipergunakan untuk Pusat Pembinaan Latihan Mahasiswa (PPLM) tarung derajat Kota Banda Aceh harus disesuaikan dengan standarNasional.

Bagaimana mungkin Pusat

Pembinaan Latihan Mahasiswa (PPLM) tarung derajat Kota Banda Aceh dapat mencapai suatu prestasi di tingkat Nasional maupun Internasional, jika prasarana latihannya saja belum mendukung sepenuhnya untuk berlatih. Prasarana latihan adalah sangat penting dan sangat mendukung dalam menunjang atletberprestasi. Seperti yang dikatatakan Adhyaksa "disadari bahwa turunnya prestasi olahraga Indonesia memang tidak lepas dari aspek-aspek seperti rendahnya perhatian pemerintah terhadap olahraga Indonesia dan terbatasnya sarana dan prasarana olahraga, minimnya kompetisi yang rutin serta kurangnya penghargaan terhadap atlet-atlet yang berprestasi" Adhyaksa Dault, Hal Aktual Keolahragaan Indonesia, (Majalah Forum Olahraga Diknas,2014:13). 
Sehingga sampai saat ini Pusat Pembinaan Latihan Mahasiswa (PPLM) tarung derajat Kota Banda Aceh hanya memaksimalkan prasarana yang ada saja dalam berprestasi.

\section{Pelaksanaan Manajemen Keuangan}

Pelaksanaan manajemen keuangan menunjukkan bahwa APBNmelaluidana dekonsentrasi dan APBDsudahterlaksana dengan baik sesuai rencana. Dana dekonsentrasi adalah dana yang dianggarkan oleh Kementrian Pemuda danOlahraga Republik Indonesiakepada Dinas Pemuda Olahraga(Dispora)Kota Banda Aceh untuk pembinaanatletPPLM cabang olahraga tarung derajat yang dikelola oleh

BalaiPusatPembinaanLatihan Mahasiswa (PPLM) tarung derajat Kota BandaAceh dan bantuan mengikuti kejuaraan antarPPLMyang dikelola oleh PengurusProvinsiTarung Dearajat Kota BandaAceh,sedangkan APBD lebih di peruntukkan kepada pembiayaan perawatan asrama PPLM Pusat

PembinaanLatihanMahasiswa(PPLM) tarung derajat KotaBandaAceh. Untuk Dana APBDPusatPembinaanLatihan Mahasiswa (PPLM)tarungderajat Kota Banda Acehdiperuntukkan biaya operasional asrama.

Untuk Dana Dekonsentrasi terbagi atas 2 jenis yaitu:

1) Pusat Pembinaan Latihan Mahasiswa (PPLM) tarung derajat Kota Banda Aceh
a) BelanjaBarang Non
OperasionalLainnya:
b) PerlengkapanLatihan
c) Pengadaan SepatuSekolah
d) Pengadaan SeragamSekolah
e) Kesehatan

2) BelanjaBahan
a) PengadaanATK
b) DokumentasidanLaporan
c) PerlengkapanKomputer
d) KonsumsiAtlet

3) Belanja JasaLainnya
a) Jasa pelatih danmassage
b) Jasa pengurusasrama
c) Jasa jasapenguruskeamanan
d) JasapengelolaPPLM
e) Jasarapatstakeholder
f) Jasaatlet

4) BelanjaPerjalanan Lainnya Dalam Negeri
a) Transportpanggil/pulang
b) Transportlokalpelatih
c) Tarnsporttryout

5) Kejuaraan antarPPLM
a) Uang sakuatlet
b) Uangsaku pelatih danofficial
c) Dokumentasidanpelaporan
d) ATK
e) Biayatransportasikejuaraan

6) Belanjadaerah
a) Biaya jasakebersihan
b) Biaya rekeningtelepon
c) Belanjaair
d) Biaya listrik
e) Belanja bahan obat-obatan
f) Belanja bahan pembantu
g) Belanja pakaiansekolah
h) Belanja pakaian olahraga
i) Biaya penjaringan atlet
j) Belanja modal pengadaan konstruksi/rehabgedung.
k) Biayamaintenance
l) Biayalainya.

m) 
Kegiatan manajemen keuangan di Pusat Pembinaan Latihan Mahasiswa (PPLM) tarung derajat Kota Banda Aceh ini dapat dilaksanakan dengan menggunakan fasilitas yang ada di Pusat Pembinaan Latihan Mahasiswa (PPLM) tarung derajat Kota Banda Aceh, menggunakan tenaga khusus di bidang keuangan yang menangani penerimaan

dan pengeluaran uang untuk keperluan operasional Pusat Pembinaan Latihan Mahasiswa (PPLM) tarung derajat Kota Banda Aceh. Berhubung PPLM ini milik Pemerintah, semua dana seutuhnya dari pemerintah dan pemerintah daerah.

Gambaran tentang pelaksanaan manajemen keuangan di atas menunjukkan bahwa dinilai dari keterlaksanaan semua kegiatan dan menggalirnya sumber dana dari pemerintah pusat dan pemerintah daerah adalah relatif baik. Tetapi mengingat alokasi dana dekonsentrasi dan APBD terbatas, sehingga pengelola hanya memaksimalkan dana yang ada untuk mengelola Pusat Pembinaan Latihan Mahasiswa (PPLM) tarung derajat Kota BandaAceh.

Dalam pelaksanaannya, manajemen keuangan Pusat Pembinaan Latihan Mahasiswa (PPLM) tarung derajat Kota Banda Aceh dikelola oleh Balai Pusat Pembinaan Latihan Mahasiswa (PPLM) tarung derajat Kota Banda Aceh bertanggung jawab kepada Kementerian Pemuda dan Olahraga RI melalui Dinas Pemuda dan Olahraga Kota Banda Aceh.

Adapunmekanisme manajemen

Keuangan Pusat Pembinaan Latihan Mahasiswa (PPLM) tarung derajat Kota Banda Aceh diberikan melalui bantuan langsung dimana disporapar menunjuk langsung kepada Balai Pusat Pembinaan Latihan Mahasiswa (PPLM) tarung derajat Kota Banda Aceh, bahwa unit pengelolaharusdalammenerimabantuan melengkapipersyaratansebegaiberikut:

a. SK Pembentukan BalaiPPLM.

b. AktaNotaris.

c. Proposal Pembinaan KegiatanPPLM.

Setelah berkas dilengkapi dilakukan pembuatan surat perjanjian kerja sama untuk dapat mencairkan dana.Mekanisme pencairan dana bantuan, tahap awalpembuatan usulan propasal dan disetujui oleh satker/kuasa penggunaan anggaran kemudian penerbitan Surat Perjanjian Kerjasama (SPK). Penerbitan kuitansi sesuai dengan permintaan yang tertera pada surat perjanjian kerjasama (SPK), kemudian Balai Pelatihan Pemuda dan Olahraga menyerahkan pertanggung jawaban kepada bendahara penerimaan pengeluaran.

Kemudian berkas pertangung jawaban diserahkan kepada KPKN Ketua Balai Pusat Pembinaan Latihan Mahasiswa (PPLM) tarung derajat Kota Banda Aceh, sebagai manajer, berfungsi sebagai otorisator, dan dilimpahi fungsi ordonator untuk memerintahkan pembayaran untuk proses pembinaan Pusat Pembinaan Latihan Mahasiswa (PPLM) tarung derajat Kota Banda Aceh. Namun tidak dibenarkan melaksanakan fungsi bendaharawan, juga dilimpahi fungsi donatur untuk menguji hak atas pembayaran proses pembinaan Pusat Pembinaan Latihan Mahasiswa (PPLM) tarung derajat Kota BandaAceh.Pada Pusat Pembinaan Latihan Mahasiswa (PPLM) tarung derajat Kota Banda Aceh Kepala Balai Pusat Pembinaan Latihan Mahasiswa (PPLM) tarung derajat Kota Banda Aceh adalah sebagai manajer berfungsi sebagai otorisator, ordonatur, tetapi hanya sebatas pengelolaan uang ekstrakurikuler saja. Pembiayaan belanja Pusat Pembinaan Latihan Mahasiswa (PPLM) tarung derajat Kota Banda Aceh, pengadaan dan sumber dana, pemanfaatan dana, pertanggungjawaban dan pengerjaan datadata keuangan Pusat Pembinaan Latihan 
Mahasiswa (PPLM) tarung derajat Kota Banda Aceh, sehingga manajemen keuangan Balai Pusat Pembinaan Latihan Mahasiswa (PPLM) tarung derajat Kota Banda Aceh dimasa yang akan datang dapat berjalanlancar,tertib, danteratur,serta mencapai tujuan pembinaan Pusat Pembinaan Latihan Mahasiswa (PPLM) tarungderajat Kota Banda
Aceh.

a) Sistem manajemen keuangan merupakan salah satu sumber daya secara langsung yang menunjang tercapainya tujuan proses Pusat Pembinaan Latihan Mahasiswa (PPLM) tarung derajat Kota Banda Aceh dan merupakan potensi yang sangat menentukan terlaksananya kegiatan Pusat Pembinaan Latihan Mahasiswa (PPLM) tarung derajat Kota Banda Aceh, disamping dengan komponenlainnya. Berikut penjelasan gambarnyaRepublik Indonesia, Undang-undang No.16 tahun 2007:

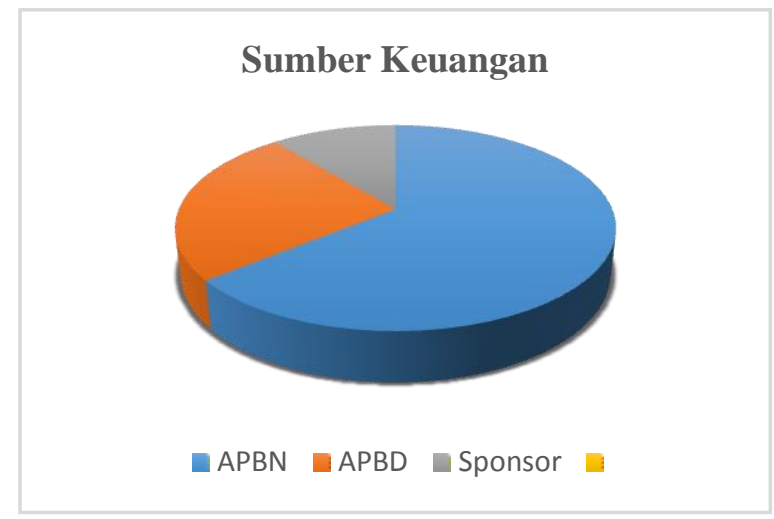

Sumber: hasil olah data, 2019

Perencanaan Program Latihan di pengembangan olahragawan pelajar

Pemusatan Pembinaan

\section{Latihan Mahasiswa}

Cabang Tarung Derajat sesuai dengan yang diharapkan KemenporaR.I

Pelaksanaan perencanaan program

di Pusat Pembinaan Latihan Mahasiswa (PPLM) tarung derajat Kota Banda Aceh sudah berjalan dengan baik, secara

bertahapsudahmenunjukkan tercapainya sasaran sesuai yang diharapkan Kemenpora. Yaitu Pendirian Pusat Pembinaan Latihan Mahasiswa (PPLM) tarung derajat Kota Banda Aceh sebagai salah satu alternatif untuk melakukanpembinaan dan potensial berbakat dan minat yang tinggi dibidang olahraga untuk dikembangkan guna mencapai prestasi optimal, baik sebagai olahragawan regional mewakili daerah maupun menjadi salah satu tumpuan pasukan olahragawan nasional untuk mewakili bangsa dan negara dalam event olahraga internasional (Deputi Bidang Peningkatan Prestasi dan Iptek Olahraga: 4) 
latihan adalah mengadakan try out yang merujuk pada buku pedoman yang dikeluarkan oleh Deputi Bidang Peningkatan Prestasi dan Iptek Olahraga Kementrian Pemuda dan Olahraga bahwa Latihan, Kompetisi, Akademik dan kesejahteraan sudah diatur yaitu kompetisi:

a) Kompetisi cabang olahraga antar PPLM dilaksanakan secaraperiodik.

b) Setiap kegiatan kompetisi nasional cabang olahraga antar PPLM wajib diikuti oleh semuaPPLM.

c) Pemerintah Daerah yang ditetapkan sebagai penyelenggara bertanggung jawab terhadap pelaksanaan kompetisi antar PPLM dengan melibatkan induk organisasi danmasyarakat.

Walapun terkadang juga terdapat kendala yaitu tidak melaksanakan tryout karenaminimmnya kompetisi dan keterbatasan anggaran.

Terkadangjuga jadwal pertandingan/kejuaraan dilakukan dengan programnya PPLM tidak sesuai, ketika

masih program masih dalam persiapan umum, tiba-tiba muncul jadwal pertandingan yang sudah didepan mata. Terkadang jadwal mundur, atlet-atlet PPLM bukanlah TNI/Polri yang siap kapansaja.

\section{KESIMPULAN}

Kesimpulan yang dimunculkan dalam penelitian ini merupakan temuantemuan penting yang peneliti temukan berdasarkan data dan analisis jugapembahasan yang sebaik-baiknya, dan temuan-temuan tersebutberupa:

1. Organisasi PPLM Tarung Derajat sudah baik yang mana sudah memiliki unsur- unsur organisasi, seperti: kepengurusan dan manajemen organisasi, anggaran dasar rumah tangga, anggaran dana, danrencanakerja.Darisemuaunsur sudah dilaksanakan dengan baik, sedangkan manajemen PPLM Tarung Derajat juga sudah cukup baik, dimana terus berupaya memfasilitasi atlet untuk berprestasi.

2. Pelaksanaan proses tahapan yang dilakukan dalam perekrutan atlet di Pusat Pembinaan Latihan Mahasiswa (PPLM) tarung derajat Kota Banda Aceh sudah berjalan dengan baik, dengan adanya pantauan atlet berprestasi dalam tiap kejuaranPopda tingkat kota/kabupaten dan provinsi serta informasi ke seluruh Dispora kota/kabupaten, terbukti dengan hasil prestasi yang diperoleh oleh atlet Pusat Pembinaan Latihan Mahasiswa (PPLM) tarung derajat Kota Banda Aceh dari tahun ketahun meningkat dengan predikatjuaraumum.

3. Sarana dan prasarana yang ada sebenarnya masih kurang memadai di tinjau dari standar yang di tetapkan okeh Kemenpora. Tempat tinggal atlet/ asrama yang apa adanya dan cenderung kurang layak untuk dipakai, sehingga dalam pelaksanaanya mereka hanya memanfaatkan yang ada untuk berprestasi.

4. Sistem pelaksanaan manajemen keuangan sudah berjalan sebagaimana mestinya, dilihat pengelolan dana dan pelaporan keuangan dengan melihat kebutuhan yang ada walau masih adanya kendala keuangan tapi masih bisa diatasi olehpengelola.

5. Perencanaan program latihan di Pusat Pembinaan Latihan Mahasiswa (PPLM) tarung derajat Kota Banda Aceh sesuai dengan yang diharapkan Kemenpora, Berdasarkan temuan 
diatas,dapatdigambarkanpelaksanaan perencanaan program di Pusat Pembinaan Latihan Mahasiswa (PPLM) tarung derajat Kota Banda Aceh sudah berjalan dengan baik, sudah menunjukkan tercapainya sasaran sesuai yang diharapkan Kemenpora. Yaitu Pendirian Pusat Pembinaan Latihan Mahasiswa (PPLM) tarung derajat Kota Banda Aceh sebagai salah satu alternatif untuk melakukanpembinaan dan pengembangan olahragawan pelajar potensial berbakat dan minat yang tinggi dibidang olahraga untuk dikembangkan guna mencapai prestasi optimal, baik sebagai olahragawan regional mewakili daerah maupun menjadi salah satu tumpuan pasukan olahragawan nasional untuk mewakili bangsa dan negara dalam even olahraga internasional.

DAFTAR PUSTAKA

Ambar, T., Sulistiyani R. (2013). Manajemen Sumber Daya Manusia: Konsep, Teori Dan Pengembangan Dalam Konteks Organisasi Publik. Yogyakarta: Graha Ilmu.

Ambarukmi, D. A. dkk. (2017). Pelatihan Pelatih Fisik Level I. Deputi Bidang Peningkatan Prestasi dan IPTEK Olahraga. Kemenpora.

Dault, A. (2014). Hal Aktual Keolahragaan Indonesia. Jakarta: Majalah Forum Olahraga

Fatah, N. (2013). Landasan Manajemen Pendidikan. Bandung: PT RemajaRosdakarya.

Harsuki. (2013). Perkembangan Olahraga Terkini, Kajian Para Pakar. Jakarta: PT Raja Grafindo Persada.

Hasibuan, S., Malayu. (2015). Manajemen Sumber Daya Manusia. Edisi Revisi. Jakarta: Bumi Aksara.

Lutan, R., Suherman, A. (2010).
Pejaskes. Jakarta:Depdiknas. Marihot, M.,

Republik Indonesia, Undang-undang No.16 tahun 2007. (2007). Tentang Penyelengaraan Keolahragaan.

Sajoto. (1995). Peningkatan Dan

Pembinaan Kekuatan Kondisi Fisik

Dalam Olahraga. Semarang:

Dahara Prize.

Sudjarwo. (1993). Ilmu Kepelatihan Dasar. Surakarta: UNS Pre

Perencanaan Pembelajaran 